\title{
European Project for Rare Diseases National Plans Development (EUROPLAN)
}

\author{
Domenica Taruscio ${ }^{1 *}$, Luciano Vittozzi ${ }^{2}$ \\ From 5th European Conference on Rare Diseases (ECRD 2010) \\ Krakow, Poland. 13-15 May 2010
}

EUROPLAN (http://www.europlanproject.eu) is a three year EU funded project (2008-2011) coordinated by the Italian National Centre for Rare Diseases (Istituto Superiore di Sanità, Italy), which involves 30 Countries and EURORDIS. The Council Recommendations on European Action in the field of Rare Diseases (RD) which was adopted by the EU Council in June 2009 calls upon Member States to adopt National Plans for RD, before the end of 2013. In line with this, EUROPLAN is an operational measure within the European strategy in the field of RD.

The project aims at a) elaborating recommendations on the different steps to develop a national plan or strategy; they will include priority areas and actions of intervention supporting the harmonisation of public health strategies on RD throughout Europe; b) select indicators for monitoring the implementation and evaluating the impact of national plans or strategies.

In order to turn the Council Recommendation into concrete actions in favour of RD patients at national level, several rare disease patient alliances, coordinated by EURORDIS in conjunction with national authorities, are organising National Conferences to be held in 16 Countries in 2010. During the National Conferences local stakeholders will discuss the EUROPLAN recommendations and the main elements of the European strategy on $\mathrm{RD}$, with the aim to assess their transferability in their own Country.

In conclusion, EUROPLAN is collecting information on EU Member States initiatives contributing to share experiences, data and effective strategies to address RD; is promoting the development of RD plan or strategy trough recommendations and indicators; is increasing

\footnotetext{
*Correspondence: domenica.taruscio@iss.it

${ }^{1}$ National Centre Rare Diseases, Istituto Superiore di Sanità, Viale Regina Elena, 299, Rome, Italy

Full list of author information is available at the end of the article
}

awareness on RD and the recommendations will also serve as an important advocacy instrument at policy level. The EUROPLAN outcomes will support and encourage EU MS in developing national health policies to ensure equal access and availability of prevention, diagnosis and treatment for citizens with RD.

\section{Author details}

${ }^{1}$ National Centre Rare Diseases, Istituto Superiore di Sanità, Viale Regina Elena, 299, Rome, Italy. 'Director of Unit, Europlan Consortium, National Centre for Rare Diseases - Istituto Superiore di Sanità, Via Giulio Venzi 24, 00163 Rome, Italy.

Published: 19 October 2010

doi:10.1186/1750-1172-5-S1-P2

Cite this article as: Taruscio and Vittozzi: European Project for Rare Diseases National Plans Development (EUROPLAN). Orphanet Journal of Rare Diseases 2010 5(Suppl 1):P2.

\section{Submit your next manuscript to BioMed Central and take full advantage of: \\ - Convenient online submission \\ - Thorough peer review \\ - No space constraints or color figure charges \\ - Immediate publication on acceptance \\ - Inclusion in PubMed, CAS, Scopus and Google Scholar \\ - Research which is freely available for redistribution \\ Submit your manuscript at www biomedcentral com/submit}

